\title{
Attitude and Graduation: Appraisal Resources in a Decision of the African Court on Human and Peoples' Rights
}

\author{
Vincent Mbahawa Chefor* Xin Zhiying Ae Mon Kyaw \\ College of Foreign Languages and Cultures, Xiamen University, \\ No.422 Siming South Road, 361005, Xiamen, China
}

\begin{abstract}
Court Judgments are classified within the legal genre of case-law, which is intended to be objective and impartial. However, despite efforts to conceal speakers' presence and subjectivity in this context, stance must be taken in pronouncing judgment. This study seeks to understand how linguistic attitude and graduation resources are expressed in legal texts and to examine the mechanisms used for this purpose. The text chosen for analysis is a 2017 judgment of the African Court on Human and Peoples' Rights (ACHPR) titled: the "African Commission on Human and Peoples' Rights V. Republic of Kenya". The applicant, in respect of the Ogiek community of the Greater Mau Forest in the Republic of Kenya, submits to the ACHPR, denouncing violation of Articles 1, 2, 4, and 17 (2) and (3) of the African Charter on Human and Peoples' Rights by the Republic of Kenya. In order to determine the semantic nature of the linguistic elements set up in this judgement, the Attitude and Graduation systems of the Appraisal theory (Martin and White 2005) in Systemic Functional Linguistics, as well as some conceptual instruments of Raccah's (2005) Semantic Structure of Points of View (SSPV) are applied to the selected corpus.
\end{abstract}

Keywords: Attitude system, Graduation system, Appraisal framework, points of view, ACHPR, Court judgement DOI: $10.7176 / J L L L / 77-04$

Publication date:March $31^{\text {st }} 2021$

\section{Introduction}

As tools meant for societal regulation, legal texts are closely connected to specific linguistic and cultural communities, serving as a mirror to the balance of power that is established between members of these communities. Although these texts are intended to be impartial, objective and neutral (Papayannis 2016), they do contain linguistic units which are indicative of the speaker's opinion (Gotti 2008; Cunillera 2012; Serpa 2013). This study therefore falls within the purview of research work aimed at demonstrating that despite their propensity for impartiality, objectivity and neutrality, legal texts contain traces of speaker's voice and point of view.

Analyzing a judgment of the African Court on Human and Peoples' Rights (ACHPR) will help shed light on the objectivity and subjectivity dichotomy specific to most legal texts, given its characteristic as representing a legal genre: the case-law (Berukstiene 2016). The interest for the legal texts derives from their nature as discursive and declaratory texts: despite their argumentative nature, they seek to conceal any trace of subjectivity and to render court decisions impartial and objective. However, in presenting its argumentation, the court reveals its own assessment of the facts in a subtle but unavoidable manner. This paper seeks to understand how this assessment is conducted: What are the linguistic mechanisms that reveal, in these types of text, the presence of the speaker and his positioning in relation to alternative voices? To carry out this analysis, Martin and White's (2005) Appraisal framework, derived from Halliday's (1985) Systemic Functional Linguistics, is used as well as the Semantics of Points of View as developed by Raccah (2005a, 2005b). Both approaches are useful in this study for the reason that they deal with the effects of the speaker's linguistic choices in the construal of textual meaning. The ultimate goal of this approach is to have some insights into the discursive and argumentative functioning of texts that represent the voice of justice.

\section{Theoretical framework}

Raccah's (2005a, 2005b) descriptive theory of the Semantic Structure of Points of View, which derives from the Language Argumentation theory by Anscombre and Ducrot (1983) has proved to be relevant for discourse analysis because it helps to account for the vital instructions of the lexical units and their effects in the construction of meaning. Any given linguistic unit is bearer of a set of semantic and pragmatic instructions which impose a certain argumentative orientation and reflect a speaker's specific point of view. Thus, the words and structures of a given language reflect the speaker's positive or negative assessments about a thing, a person or an attitude during their utterance and about the situation concerned by the utterance (Anscombre and Ducrot 1983). According to Ducrot (1984: 205), the speaker generates "utterances and organizes them into points of view and attitudes" and the speaker's position can be manifested through engagement or disengagement with regards to the points of view attributed to various utterances. The theory of the Semantic Structure of Points of View borrowed the concepts of argumentative orientation, point of view, and semantic instruction from the Language Argumentation theory and developed them to formulate its own objectives: 
Based on the fact that an argument is intended to convey a point of view while supposing other points of view are admitted, the Semantics of Points of View proposes to describe in a unified system both the argumentative orientations and the points of view, tasking semantics to describe the constraints that linguistic units impose on the points of view targeted by utterances, but also on the points of view assumed by these utterances (Raccah 2008: 79).

Raccah (2005a) distinguishes between euphoric and dysphoric words when referring to evaluations associated with words in any situation. According to this author, the euphoric units are those which always convey positive points of view and the dysphoric ones are those which always express negative points of view. Words that are neither euphoric nor dysphoric do not have explicit instruction, but this does not mean that they cannot express positive or negative evaluation based on the background and ideology of the utterer.

The concepts of point of view, attitude and voice also form the core of the Appraisal theory developed by Martin and White (2005) and White (2003). Deriving from Halliday's (1985) Systemic Functional Linguistics (SFL) developed in the late 1960s and revised in 1985, 1994 and 2004 (Chefor 2020), this theory is interested in linguistic markers which reveal the subjective presence of the speaker in a text, his position with regards to the receiver and his evaluation system (Martin and White 2005: 164). The Appraisal framework proposes a classification system of the effects created by different speaker choices. As illustrated in figure 1 bellow, this classification is organized into three main interdependent semantic subsystems or domains, namely engagement, attitude and graduation. The framework presents a systematic organization of 'the semantic resources used to negotiate emotions, judgements and valuation, alongside resources for amplifying and engaging with these evaluations' (Martin 2000: 145) and its linguistic analysis mainly focuses on how evaluation is expressed implicitly as well as explicitly. The three semantic systems that organize the appraisal framework are illustrated in figure 1 below.

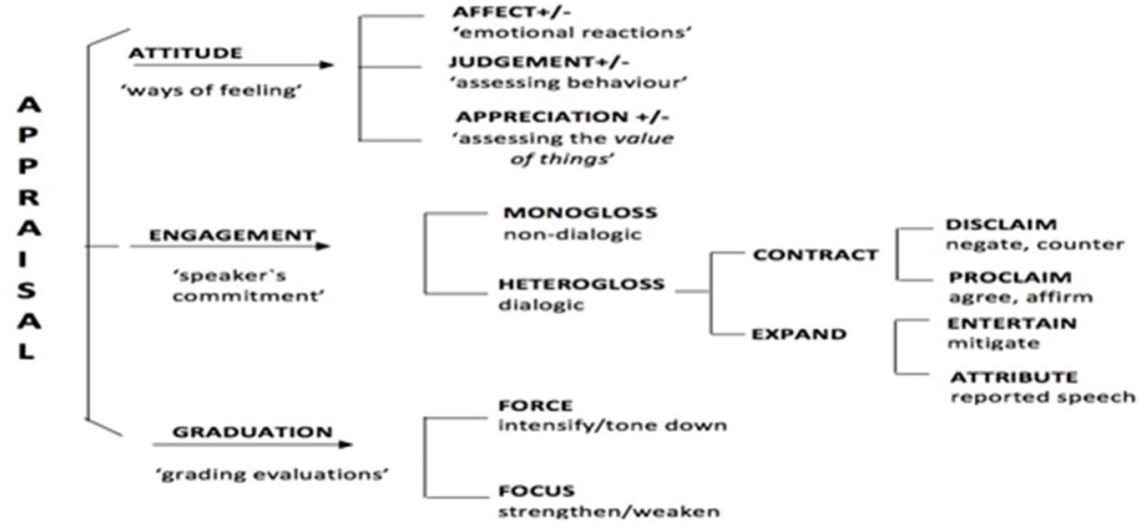

Figure 1. The System of Appraisal (Martin and White, 2005: 40)

In this study, the Appraisal framework will therefore be used to analyze the expression of evaluation in the ACHPR judgment, focusing on the two sub-systems of Attitude and Graduation. The strategies provided by these two sub-systems probably have an impact on the argumentative force of discourse as conceived by the Semantics of Points of View, which is the second theoretical backing of this analysis.

\section{Attitude and graduation in the decision of the ACHPR}

3.1 The corpus of study

As it is known, a judgment is a decision by a court or other other tribunal that resolves a controversy and determines the rights and obligations of the parties. From the legal genre view point, it is a text that falls within the realm of case-law (Berukstiene and Magnus 2016). In general, these texts are very complex owing of their hybrid nature as they are developed based on other legal texts (with fragments of laws, appeals, other judgments, etc.), and because of their polyphonic nature, since they incorporate statements by several speakers (Ducrot 1984). At the same time, they are very diverse texts in the sense that a judgment may present a variety of legal situations (according to the type of appeal, the type of decision taken by the Court - cassation or rejection, etc.) and a wide variety of themes (the branches of law under which a judgment may be classified are numerous, same as the different daily life situations to which they refer).

The judgment on which this analysis is based was delivered on 26 May 2017 by the African Court on Human and Peoples' Rights. With 70 pages, 226 paragraphs, 9 sections, and several subsections, it now forms part of the jurisprudence of the ACHPR on the fundamental rights of individuals, which has a great influence on the laws of African Union member state countries. Titled “African Commission on Human and Peoples' Rights V. Republic of Kenya", the judgment is published on the ACHPR's website (http://fr.african-court.org) and can be summarized as follows: The Application was in respect of the Ogiek community of the Greater Mau Forest in the Republic of Kenya. It alleged that the Ogiek are an indigenous minority ethnic group in Kenya comprising of about 20,000 
members, about 15,000 of whom inhabit the Greater Mau Forest complex, a land mass of about 400,000 hectares straddling about seven administrative districts. According to the Applicant, in October 2009, through the Kenya Forestry Service, the Kenyan Government issued a thirty (30) days eviction notice to the Ogiek and other settlers of the Mau Forest, demanding that they move out of the forest on the grounds that the forest constituted a reserved water catchment zone, and was in any event part and parcel of government land under Section 4 of the Government's Land Act. The Applicant alleged violation of Articles 1, 2, 4, and 17 (2) and (3) of the Charter and prayed the Court to order the Respondent to:

a. Halt the eviction of the Ogiek from the East Mau Forest and refrain from harassing, intimidating, or interfering with the community's traditional livelihoods;

b. Recognize the Ogiek's historic land, and issue it with legal title that is preceded by consultative demarcation of the land by the Government and Ogiek Community, and for the Respondent to revise its laws to accommodate communal ownership of property; and

c. Pay compensation to the community for all the loss they have suffered through the loss of their property, development, natural resources and also freedom to practice their religion and culture.

In its judgment, the court found that, apart from Article 4, the Respondent state had violated Articles 1, 2, 8, 14, 17(2) and (3), 21 and 22 of the African Charter on Human and Peoples' Rights in its relations with the Ogiek Community of the Greater Mau Forest.

\subsection{The analytical process}

To approach the linguistic elements that express the evaluation and intervention of the ACHPR in the text, this study specially examines the answers of the Court to the applicant's allegations. These answers are presented in seventeen sections of the Court's judgment and entitled "The Court's Assessment". Figure 2 below is an illustration of the sequencing of each section of the overall court judgment.

\section{ON THE MERITS}

\section{A. The Ogieks as an Indigenous Population}

- Applicant's Submission

- Respondent's Submission

- The Court's Assessment

B. Alleged Violation of Article 14 of the Charter

- Applicant's Submission

- Respondent's Submission

- The Court's Assessment

C. Alleged Violation of Article $\mathbf{2}$ of the Charter

- Applicant's Submission

- Respondent's Submission

- The Court's Assessment

D. Alleged Violation of Article 4 of the Charter

- Applicant's Submission

- Respondent's Submission

- The Court's Assessment

Figure 2. Structure of a section of the ACHPR Judgment (Pages 28-46)

In the various sections under study, the Court iterates the arguments of the parties - Applicant and Respondent state - and at the same time it develops its own opinions on these arguments. Naturally, these opinions, as well as any judgment, can only be based on the law and jurisprudence. They must therefore be motivated and seen as objective and impartial. These are the sections that will provide data relating to the way in which the Court's assessments are expressed.

\section{Findings and discussion}

The Court must rule on the allegations which gave rise to the judicial proceedings, and which concern the conduct of the Republic of Kenya towards the applicant and the situation experienced by the Ogiek Community of the Greater Mau Forest in respect of whom the applicant filed the complaint. Throughout its argumentation, the voice 
of the judicial authority reiterates each allegation and, before reaching the final resolution, it states its assessment of the ideational content. The behavior of the Kenyan authorities is evaluated indirectly through a review of the investigation and the jurisdictional supervisory measures required by law. The situation experienced by the Ogiek Community of the Greater Mau Forest is evaluated, in turn, through the assessment of evidence and gravity of facts. The subsequent section expatiates on the specific way in which the evaluations of these contents are expressed.

\subsection{Attitude}

Attitude includes those meanings by which participants and processes in texts/speeches are given an intersubjective value or assessment by reference either to emotional responses or to systems of culturallydetermined value systems. It is a system of interpersonal meanings which offers an analytical framework to systematically identify and classify expressions or emotional reactions and opinions. As illustrated on figure 3 below, attitudinal expressions can be categorized into three different types, namely: Affect (expressions of emotion), Judgment (dealing with the evaluation of human behavior in relation to social norms), and Appreciation (which evaluates other features like things, actions or phenomena).

The first distinction in analyzing Attitude is often made between positive [+] and negative [-] expressions (Bakar 2014). Theses attitudinal expressions can be direct, explicit, through lexical units and evaluative grammatical constructions, or indirect, when linguistic choices suggest evaluations related to values, knowledge, and points of view shared by a given cultural community.

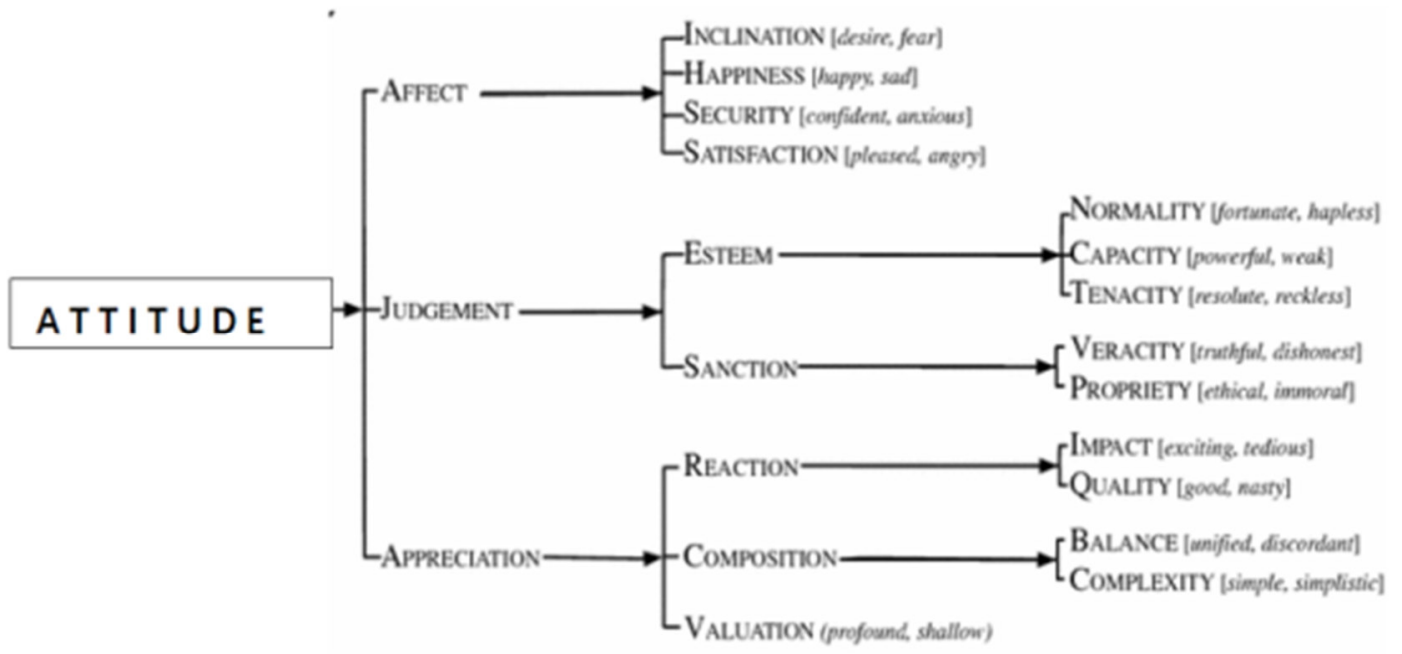

Figure 3. The System of Attitude, adapted from Martin and White (2005)

Taking into account the nature of the elements that are evaluated in the corpus of this study (the investigation, supervisory measures, etc.), what is considered here is the appreciation category. As it will be seen in examples bellow, in expressing its evaluation, the Court utilizes lexical units which range from semantically vague and undefined (used to refer to arguments which, according to the Court, could prove the existence of abuse against someone), seemingly neutral, in the sense that only the context makes it possible to identify a positive or negative value. Thus, they reflect a desire for objectivity in presenting reported facts and in applying the law. The Court also uses these types of lexical units to talk about inquiries, investigations and jurisdictional supervisory measures put in place by the defendant party.

4.1.1 The adjectives effective, sufficient, and adequate

They are used to speak about the investigation required by law and the investigation carried out by the Kenyan authorities. These adjectives appear in a high number of occurrences $(8$ occurrences for effective and 9 occurrences for adequate). For example:

(1) In its earlier judgments, the Court has decided that domestic remedies to be exhausted must be available, effective and sufficient and must not be unduly prolonged. (paragraph 93)

(2) In view of the above, the Respondent has violated article 1 of the Charter by not taking adequate legislative and other measures to give effect to the rights enshrined under article 2, 8, 14, 17 (2) and (3), 21 and 22 of the Charter. (paragraph 217)

Perhaps aware of this vagueness, the speaker introduces a definition but is also very vague from a semantic point of view, because it also contains undetermined terms like justified, reasonable, etc. Gardin (2009) holds that adjectives are the main linguistic forms which can represent Attitude, as well as the most natural way of expressing an evaluation. However, in the ACHPR judgment, it seems that they do not convey explicit evaluations. 
Effective, sufficient and adequate, as adjectives, can have a positive or negative meaning depending on the context. In the judgment analyzed and in relation to the investigation which is supposed to have been examined, the adjectives have a positive value as they direct the statement towards a conclusion that suggests the fact of being consistent with the law. This conclusion is positive in the area of justice, as well as in society and culture where the text fits. The Court's statement presents a vision which emphasizes the importance of legality.

4.1.2 The adjectives particular, specific, and clear

These adjectives are used to define trials and motions. They are used notably when the Court rules on the alleged violation of Articles 14, 17(2) and (3) of the African Charter on Human and Peoples' Rights and on the status of the Ogieks as an indigenous population. These lexical units expressing an idea of precision and accurateness convey a positive meaning in this context because they direct statements toward a conclusion that suggests the fact of being consistent with the law.

(1) [...] In this respect, culture should be construed in its widest sense encompassing the total way of life of a particular group, including the group's languages, symbols such as dressing codes and the manner the group constructs shelter; engages in certain economic activities, produces items for survival; rituals such as the group's particular way of dealing with problems and practicing spiritual ceremonies [...] (paragraph 179).

(2) In view of the above, the Court recognizes the Ogieks as an indigenous population that is part of the Kenyan people having a particular status and deserving special protection deriving from their vulnerability (paragraph 112).

(3) From the foregoing, the Court deduces that for the identification and understanding of the concept of indigenous populations, the relevant factors to consider are the presence of priority in time with respect to the occupation and use of a specific territory [...] (paragraph 107).

(4) According to the expert witness called by the Applicant, the Land Act 2012, inspired by the Constitution "is not perfect but is sound". She submitted that this law has very clear provisions that ancestral land and huntergatherer lands are community lands [...] (Paragraph 119).

4.1.3 Nominals such as subjugation, marginalization, dispossession, exclusion

They have been used in the Court's description of the situation of the Ogiek Community of the Greater Mau Forest. These are not explicitly evaluative lexical units, but they have a high meaning potential in the culture where they are used (they are associated with ill-treatment, the idea of pain, attacks on individuals, etc.) and they convey a negative value in the analyzed context. All of these lexical units have an indirect effect on the assessment of the behavior of the authorities of the Republic of Kenya: implicitly they lead to a conclusion of the type "The Republic of Kenya did not act in accordance with the law". Thus, the Republic of Kenya is evaluated negatively.

4.1.4 Lexemes such as appropriate and proscribe

They are used to talk about objection on non-compliance with Rule 40(5) of the Rules of Proceeding (Exhaustion of local remedies). Their apparent semantic and argumentative neutrality is again nuanced by the presence of graduation elements (strictly, etc.), which shows the intervention of the speaker as seen in the following examples:

(1) The Court also emphasizes that [...]. What must rather be demonstrated is that, before a matter is filed before an international human rights body, like this Court, the Respondent has had an opportunity to deal with such matter through the appropriate domestic proceedings. Once an Applicant proves that a matter has passed through the appropriate domestic judicial proceedings, the requirement of exhaustion of local remedies shall be presumed to be satisfied [...] (Paragraph 94).

(2) [...] The provision strictly proscribes any distinction, exclusion or preference made on the basis of race, colour, sex, religion, political opinion, national extraction or social origin, which has the effect of nullifying or impairing equality of opportunity or treatment. (Paragraph 137).

Some lexical units with semantic precision such as unlawful discrimination, irreparable harm, eviction, as shown in the following examples, are also used to refer to the treatment denounced by the applicant in some of the allegations. Most of these units are dysphoric because they are negative in any given situation.

(1) $[\ldots]$ the differential treatment of the Ogieks and other similar indigenous and minority groups within Kenya, in relation to the lack of respect for their property rights, religious and cultural rights, and right to life, natural resources and development under the relevant laws, constitutes unlawful discrimination and is a violation of Article 2 of the Charter. (Paragraph 133).

(2) On 15 March 2013, the Court issued an Order for Provisional Measures directed at the Respondent on the basis that there was a situation of extreme gravity and urgency as well as a risk of irreparable harm to the Ogieks. (Paragraph 4).

(3) Their suffering as a result of evictions from their ancestral lands and forced assimilation and the very lack of recognition of their status as a tribe or indigenous population attest to the persistent marginalization that the Ogieks have experienced for decades. (Paragraph 111).

The description of the facts using these terms offers a negative view of the situation suffered by the applicant and, indirectly, a negative assessment of the behavior of the responsible Kenyan authorities. However, ACHPR's support for this negative assessment is immediately invalidated by the use of the conditional past, could have, 
which marks an enunciative distancing. This verbal inflection suggests an idea of virtuality and expresses a low degree of intensity from the point of view of Engagement. In the judgment, the ACHPR therefore uses the conditional mode to attribute statements to the applicant's voice and to show that she (the Court) is not responsible for those statements.

\subsection{Graduation}

Graduation has to do with grading or scaling values, either in terms of the interpersonal force which the speaker attaches to an utterance or the preciseness or sharpness of focus with which an item demonstrates a valeur relationship. Through Graduation the speaker is able to indicate the meaning and scope of evaluations and assertions, by modifying the intensity or specificity of what has been said (Hood and Martin 2005: 200; Navarro 2014: 17). As illustrated in figure 4 bellow, this system is made up of two subsystems: Force, which corresponds to graduation based on intensity (of the opinion emitted) or quantity; and Focus, which relates to the prototypicality of phenomena, which can be upscaled such as true champion, or downscaled kind of blue, in which the focus may become sharper or more blurred (Martin and White, 2005: 154).

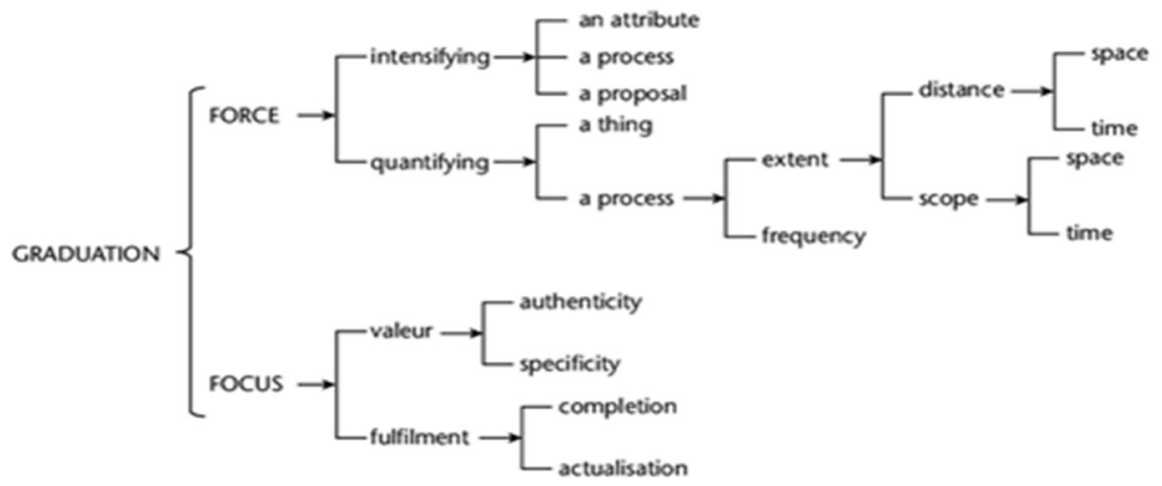

Figure 4. The system of Graduation (Martin and White, 2005: 154)

This study only focuses on the first subsystem, Force, which can be expressed in two ways as mentioned above: through Quantification (many tears, small businesses), or through Intensification (totally extinct, slightly worried) (Martin and White, 2005: 154). In the examined corpus, the ACHPR's expression of evaluation by means of a sizable number of lexical units with semantic imprecision, as mentioned in the previous section, is compensated by the presence of other linguistic options which reveal the subjectivity of the speaker and which belong to the Graduation system. Thus, several lexical and grammatical elements related to the category of Force are identified in the text. These elements graduate the appraisals made by the speaker, either through the expression of Quantity (for concrete and abstract entities) or through Intensity (for qualities and processes).

4.2.1 Lexemes conveying Force to statements by expressing the Quantity of things:

reasonably, largely, not sufficiently and inordinate

These lexical units go along with those units with semantic imprecision mentioned earlier in speaking about the investigation required by law and the investigation carried out by the Kenyan authorities (effective, adequate, etc.) as well as in describing the situation of the Ogiek Community of the Greater Mau Forest (subjugation, marginalization, dispossession, exclusion, etc.).

The modifying adverbs reasonably, largely, and not sufficiently in their context of usage suggest some level of requirement for the proceedings to be considered regular and legal and this requirement turns out not to be fulfilled as the conclusion contained in the Court's statement about the proceedings bears a negative evaluation as seen in the following examples:

(1) In the instant Application, the Court notes that [...] the Respondent, can thus reasonably be considered to have had the opportunity to address the matter before it was brought before this Court (Paragraph 95).

(2) Furthermore, from available records, the Court notes that [...] in the instant Application, the records before this Court show that the prolonged proceedings before the domestic courts were largely occasioned by the actions of the Respondent, including numerous absences during Court proceedings and failure to timely defend its case [...] (Paragraph 96).

(3) $[. .$.$] the Court reiterates that the Respondent has not sufficiently demonstrated that this alleged shift and$ transformation in the lifestyle of the Ogieks has entirely eliminated their cultural distinctiveness [...] (Paragraph 185).

In the statement in example (11) above, the adverbial form not sufficiently bears an explicit negative evaluation with a high degree of intensity, but at the same time the Court distances itself from the statement with the use of the adjective alleged thereby attributing the statement to another speaker (the Applicant).

The adjective inordinate intensifies the idea of insufficiency conveyed by the previous units because it represents 
absolute negation:

(1) $[\ldots]$ In view of this, the Court holds that the Respondent's contention imputing the inordinate delays in the domestic system to the adversarial nature of its judicial procedures is not plausible.

\section{Concluding remarks}

The linguistic mechanisms analyzed in the selected corpus contribute to the construction of objectivity and at the same time they reveal some subjective positioning. Thus, the judicial authority formulates its decision while avoiding the use of explicit evaluative lexicon but, at the same time, seemingly neutral lexemes are specified using Attitude and Graduation strategies. These strategies evaluate ideational content in an indirect way; the speaker situates them subjectively at a level that involves relative values. Several elements of the Force subsystem expressing Quantity and Intensity contribute to reinforcing or building a negative evaluation. With regards to the Semantic structure of Points of View, the analysis has revealed how the speaker's language choices can affect the argumentative force of a statement: they bring about a certain argumentative orientation and lead to conclusions while reflecting positive or negative appreciations. To complete these results, a quantitative study of the distribution of evaluative mechanisms and options for graduation could be envisaged on the corpus. A study of the Engagement system could also be very useful to identify the image that the Court projects of itself and it positioning in relation to the points of view of others. This could help provide more data on discursive issues in the legal texts.

\section{References}

Anscombre, J. C. \& Ducrot, O. (1983). L’Argumentation dans la langue, Liège, Mardaga, 1983.

Berukstiene, D. (2016). Legal Discourse Reconsidered: Genres of Legal Texts. Comparative Legilinguistics, 28 (89). DOI: $10.14746 / \mathrm{cl} .2016 .28 .5$.

Chefor, V.M. (2000). Understanding the Use of Deixis in Paul Biya's 2019 Message to Cameroonian Youth. International Journal of English Language and Linguistics Research, 8 (1).

Domenech, M. C. (2012). Les formules impersonnelles dans les textes judiciaires français et leur traduction en espagnol. Babel. International Journal of Translation, 58 (2).

Ducrot, O. (1984). Esquisse d'une théorie polyphonique de l'énonciation. Le dire et le dit, Paris, Minuit.

Gardin, P. (2009). Application de la théorie de l'Appraisal à l'analyse d'opinion. MajecSTIC. http://majecstic2009.univ-avignon.fr/Actes_MajeSTIC_RJCP/ MajeSTIC/articles/1272.pdf (accessed 19 November 2019).

Gotti, M. (2008). El discurso jurídico en diversas lenguas y culturas: tendencia a la globalización e identidades locales. Signos, 41 (68).

Halliday, M. A. K. (1985). An Introduction to Functional Grammar. London: Edward Arnold; 1st edition.

Hood, S. \& Martin, J. R. (2005). Invocación de actitudes: el juego de la gradación de la valoración en el discurso. Signos, 38 (58)

Martin, J. R. \& White, P. R. (2005). The Language of Evaluation, Appraisal in English, Londres/New York, Palgrave Macmillan.

Martin, J. R. (2000). Beyond exchange: Appraisal systems in English. S. Hunston and G. Thompson (eds) Evaluation in Text. Oxford: Oxford University Press.

Munday, J. (2015). Engagement and graduation resources as markers of translator/interpreter positioning. Target. $27(3)$.

Navarro, F. (2014). Gradación y compromiso en escritura académica estudiantil de humanidades. Análisis contrastivo des de la teoría de la valoración. Estudios de Lingüistica Aplicada, 32 (60).

Papayannis, D. M. (2018). Independence, Impartiality and Neutrality in Legal Adjudication, Revus, http://journals.openedition.org/revus/3546. ( accessed 20 November 2020).

Raccah, P. Y. (2005a). Une sémantique du point de vue : de l'intersubjectivité à l'adhésion. Discours Social, 21, 205-249.

Raccah, P. Y. (2005c). Une description de l'excessivité en sémantique des points de vue. Intensité, comparaison, dégré. Travaux linguistiques du CERLICO, 18, 171-190.

Raccah P. Y. (2008). Contraintes linguistiques et compréhension des énoncés : la langue comme outil de manipulation. Entretiens d'orthophonie. Paris, Expansion Formation et Éditions.

Serpa, C. (2015). Significados de probabilidad y fuerza en los textos legislativos, I Vardande. Revista Electrónica de Semiótica y Fenomenología Jurídicas, 1 (1). http://i-vardande.com/index.php/vard/article/view/107/91. (accessed 19 November 2020).

White, P. R. (2003). 'Beyond modality and hedging: a dialogic view of the language of intersubjective stance'. Text - Special Edition on Appraisal. 259-84. 
Appendix

Extracts from ACHPR Judgement in the matter: African Commission on Human and Peoples' Rights V. Republic of Kenya

\author{
AFRICAN COMMISSION ON HUMAN AND PEOPLES' RIGHTS \\ $\mathrm{V}$. \\ REPUBLIC OF KENYA \\ APPLICATION 006/2012 \\ JUDGEMENT \\ 26 MAY 2017
}

\title{
VII. ON THE MERITS
}

101. In its Application, the Applicant alleges violation of Articles 1, 2, 4, 8, 14, 17(2) and (3), 21 and 22 of the Charter. Given the nature of the subject matter of the application, the Court will commence with the alleged violation of Article 14, then examine articles 2, 4, 8, 14, 17(2) and (3), 21,22 and 1

102. However, having noted that most of the allegations made by the Applicant hinge on the question as to whether or not the Ogieks constitute an indigenous population. This issue is central to the determination of the merits of the alleged violations and shall be dealt with from the onset.

\section{A. On the Ogieks as an Indigenous Population}

\section{The Court's Assessment}

105. The Court notes that the concept of indigenous population is not defined in the Charter. For that matter, there is no universally accepted definition of "indigenous population" in other international human rights instruments. There have, however, been efforts to define indigenous populations. ${ }^{13}$ In this regard, the Court draws inspiration from the work of the Commission through its Working Group on Indigenous Populations/Communities. The Working Group has adopted the following criteria to identify indigenous populations: "

i. Self-identification;

ii. A special attachment to and use of their traditional land whereby their ancestral land and territory have a fundamental importance for their collective physical and cultural survival as peoples; and

iii. A state of subjugation, marginalisation, dispossession, exclusion, or discrimination because these peoples have different cultures, ways of life or mode of production than the national hegemonic and dominant model. "14

106. The Court also draws inspiration from the work of the United Nations Special Rapporteur on Minorities, which specifies the criteria to identify indigenous populations as follows:

i. That indigenous people can be appropriately considered as "Indigenous communities, peoples and nations which having a historical continuity with pre-invasion and pre-colonial societies that developed on their territories, consider themselves distinct from other sectors of societies now prevailing in those territories, or parts of them. They form at present non -dominant sectors of society and are determined to preserve, develop, and transmit to future generations, their ancestral territories, and their ethnic identity, as the basis of their continued existence as peoples, in accordance with their own cultural patterns, social institutions and legal systems"; 15

ii. That an indigenous individual for the same purposes is "... one who belongs to these indigenous populations through self-identification as indigenous (group consciousness) and is recognised and accepted by these populations as one of its members (acceptance by the group). This preserves for these communities the sovereign right and power to decide who belongs to them, without external interference". ${ }^{16}$

107. From the foregoing, the Court deduces that for the identification and understanding of the concept of indigenous populations, the relevant factors to consider are the presence of priority in time with respect to the occupation and use of a specific territory; a voluntary perpetuation of cultural distinctiveness, which may include aspects of language, social organisation, religion and spiritual values, modes of production, laws and institutions; self-identification as well as recognition by other groups, or by State authorities that they are a distinct collectivity; and an experience of subjugation, marginalisation, dispossession, exclusion or discrimination, whether or not these conditions persist. ${ }^{17}$

108. These criteria generally reflect the current normative standards to identify indigenous populations in international law. The Court deems it appropriate, by virtue of Article 60 and 61 of the Charter, which allows it to draw inspiration from other human rights instruments to apply these criteria to this Application.

109. With respect to the issue of priority in time, different reports and submissions by the parties filed before the Court reveal that the Ogieks have priority in time, with respect to the occupation and use of the Mau Forest. ${ }^{18}$ These reports affirm the Applicant's assertion that the Mau Forest is the Ogieks' ancestral home. ${ }^{19}$ The most 
salient feature of most indigenous populations is their strong attachment with nature, particularly, land and the natural environment. Their survival in a particular way depends on unhindered access to and use of their traditional land and the natural resources thereon. In this regard, the Ogieks, as a hunter-gat here $r$ community, have for centuries depended on the Mau Forest for their residence and as a source of their livelihood.

110. The Ogieks also exhibit a voluntary perpetuation of cultural distinctiveness, which includes aspects of language, social organisation, religious, cultural and spiritual values, modes of production, laws and institution ${ }^{20}$ through self-identification and recognition by other groups and by State authorities ${ }^{21}$, as a distinct group. Despite the fact that the Ogieks are divided into clans made up of patrilineal lineages each with its own name and area of habitation, they have their own language, albeit currently spoken by very few and more importantly, social norms and forms of subsistence, which make them distinct from other neighbouring tribes. ${ }^{22}$ They are also identified by these neighbouring tribes, such as the Maasai, Kipsigis and Nandi, with whom they have had regular interaction, as distinct 'neighbours' and as a distinct group. ${ }^{23}$

111. The records before this Court show that the Ogieks have suffered from continued subjugation, and marginalisation. ${ }^{24}$ Their suffering as a result of evictions from their ancestral lands and forced assimilation and the very lack of recognition of their status as a tribe or indigenous population attest to the persistent marginalisation that the

Ogieks have experienced for decades. ${ }^{25}$

112. In view of the above, the Court recognises the Ogieks as an indigenous population that is part of the Kenyan people having a particular status and deserving special protection deriving from their vulnerability.

113. The Court will now proceed to examine the articles alleged to have been violated

by the Respondent.

\section{B. Alleged violation of Article 14 of the Charter}

\section{The Court's Assessment}

122. Article 14 of the Charter provides as follows: "The right to property shall be guaranteed. It may only be encroached upon in the interest of public need or in the general interest of the community and in accordance with the provisions of appropriate laws."

123. The Court observes that, although addressed in the part of the Charter which enshrines the rights recognised for individuals, the right to property as guaranteed by Article 14 may also apply to groups or communities; in effect, the right can be individual or collective.

124. The Court is also of the view that, in its classical conception, the right to property usually refers to three elements namely: the right to use the thing that is the subject of the right (usus), the right to enjoy the fruit thereof (fructus) and the right to dispose of the thing, that is, the right to transfer it (abusus).

125. However, to determine the extent of the rights recognised for indigenous communities in their ancestral lands as in the instant case, the Court holds that Article 14 of the Charter must be interpreted in light of the applicable principles especially by the United Nations.

126. In this regard, Article 26 of the United Nations General Assembly Declaration

61/295 on the Rights of Indigenous Peoples adopted by the General Assembly on 13

September 2007, provides as follows:

"1. Indigenous peoples have the right to the lands, territories and resources which they have traditionally owned, occupied or otherwise used or acquired.

2. Indigenous peoples have the right to own, use, develop and control the lands, territories and resources that they possess by reason of traditional ownership or other traditional occupation or use, as well as those which they have otherwise acquired.

3. States shall give legal recognition and protection to these lands, territories and resources. Such recognition shall be conducted with due respect to the customs, traditions and land tenure systems of the indigenous peoples concerned."

127. It follows in particular from Article 26 (2) of the Declaration that the rights that can be recognised for indigenous peoples/communities on their ancestral lands are variable and do not necessarily entail the right of ownership in its classical meaning, including the right to dispose thereof (abusus). Without excluding the right to property in the traditional sense, this provision places greater emphasis on the rights of possession, occupation, use/utilization of land.

128. In the instant case, the Respondent does not dispute that the Ogiek Community has occupied lands in the Mau Forest since time immemorial. In the circumstances, since the Court has already held that the Ogieks constitute an indigenous community (supra paragraph 112), it holds, on the basis of Article 14 of the Charter read in light of the above-mentioned United Nations Declaration, that they have the right to occupy their ancestral lands, as well as use and enjoy the said lands.

129. However, Article 14 envisages the possibility where a right to property including land may be restricted provided that such restriction is in the public interest and is also necessary and proportional. ${ }^{27}$ 
130. In the instant case, the Respondent's public interest justification for evicting the Ogieks from the Mau Forest has been the preservation of the natural ecosystem. Nevertheless, it has not provided any evidence to the effect that the Ogieks' continued presence in the area is the main cause for the depletion of natural environment in the area. Different reports prepared by or in collaboration with the Respondent on the situation of the Mau Forest also reveal that the main causes of the environmental degradation are encroachments upon the land by other groups and government excisions for settlements and ill-advised logging concessions. ${ }^{28}$ In its pleadings, the Respondent also concedes that "the Mau Forest degradation cannot entirely be associated or is not associable to the Ogiek people". ${ }^{29}$ In this circumstance, the Court is of the view that the continued denial of access to and eviction from the Mau Forest of the Ogiek population cannot be necessary or proportionate to achieve the purported justification of preserving the natural ecosystem of the Mau Forest.

131. In view of the foregoing considerations, the Court holds that by expelling the Ogieks from their ancestral lands against their will, without prior consultation and without respecting the conditions of expulsion in the interest of public need, the Respondent violated their rights to land as defined above and as guaranteed by Article 14 of the Charter read in light of the United Nations Declaration on the Rights of Indigenous Peoples of 2007.

\section{Alleged violation of Article 2 of the Charter}

\section{The Court's Assessment}

136. Article 2 of the Charter provides that:

"Every individual shall be entitled to the enjoyment of the rights and freedoms recognized and guaranteed in the present Charter without distinction of any kind such as race, ethnic group, colour, sex, language, religion, political or any other opinion, birth or any status."

137. Article 2 of the Charter is imperative for the respect and enjoyment of all other rights and freedoms protected in the Charter. The provision strictly proscribes any distinction, exclusion or preference made on the basis of race, colour, sex, religion, political opinion, national extraction or social origin, which has the effect of nullifying or impairing equality of opportunity or treatment.

138. The right not to be discriminated against is related to the right to equality before the law and equal protection of the law as guaranteed by Article 3 of the Charter. ${ }^{31}$ The scope of the right to non-discrimination extends beyond the right to equal treatment by the law and also has practical dimension in that individuals should in fact be able to enjoy the rights enshrined in the Charter without distinction of any kind relating to their race, colour, sex, religion, political opinion, national extraction or social origin, or any other status. The expression 'any other status' under Article 2 encompasses those cases of discrimination, which could not have been foreseen during the adoption of the Charter. In determining whether a ground falls under this category, the Court shall take into account the general spirit of the Charter.

139. In terms of Article 2 of the Charter, while distinctions or differential treatment on grounds specified therein are generally proscribed, it should be pointed out that not all forms of distinction can be considered as discrimination . A distinction or differential treatment becomes discrimination, and hence, contrary to Article 2 , when it does not have objective and reasonable justification and, in the circumstances where it is not necessary and proportional. ${ }^{32}$

140. In the instant case, the Court notes that the Respondent's national laws as they were before 2010, including the Constitution of Kenya 1969 (as Amended in 1997), the Government Lands Act Chapter 280, Registered Land Act Chapter 300, Trust Land Act Chapter 285 and the Forest Act Chapter 385, recognised only the concept of ethnic groups or tribes. While some of these laws were enacted during the colonial era, the Respondent maintained them with few amendments or their effect persisted to date even after independence in 1963.

141. In so far as the Ogieks are concerned, the Court notes from the records available before it that their request for recognition as a tribe goes back to the colonial period, where their request was rejected by the then Kenya Land Commission in 1933, asserting that "they [the Ogieks] were a savage and barbaric people who deserved no tribal status" and consequently, the Commission proposed that "they should become members of and be absorbed into the tribe in which they have the most affinity". ${ }^{33}$ The denial of their request for recognition as a tribe also denied them access to their own land as, at the time, only those who had tribal status were given land as "special reserves" or "communal reserves". This has been the case since independence and is still continuing. ${ }^{34}$ In contrast, other ethnic groups such as the Maasai, have been recognised as tribes and consequently, been able to enjoy all related rights derived from such recognition, thus proving differential treatment. ${ }^{35}$

142. The Court accordingly finds that, if other groups which are in the same category of communities, which lead a traditional way of life and with cultural distinctiveness highly dependent on the natural environment as the Ogieks, were granted recognition of their status and the resultant rights, the refusal of the Respondent to recognise and grant the same rights to the Ogieks, due to their way of life as a hunter-gatherer community 
amounts to ' distinction ' based on ethnicity and/or 'other status' in terms of Article 2 of the Charter.

143. With regard to the Respondent's submission that, following the adoption of a new Constitution in 2010, all Kenyans enjoy equal opportunities in terms of education, health, employment, and access to justice and there is no discrimination among different tribes in Kenya including the Ogieks, the Court notes that indeed the 2010 Constitution of Kenya recognises and accords special protection to indigenous populations as part of "marginalised community" and the Ogieks could theoretically fit into that category and benefit from the protection of such constitutional safeguards. All the same, this does not diminish the responsibility of the Respondent with respect to the violations of the rights of the Ogieks not to be discriminated against between the time the Respondent became a Party to the Charter and when the Respondent's new Constitution was enacted.

144. In addition, as stated above, the prohibition of discrimination may not be fully guaranteed with the enactment of laws which condemn discrimination; the right can be effective only when it is actually respected and, in this vein, the persisting eviction of the Ogieks, the failure of the authorities of the Respondent to stop such evictions and to comply with the decisions of the national courts demonstrate that the new Constitution and the institutions which the Respondent has set up to remedy past or on-going injustices are not fully effective.

145. On the Respondent's purported justification that the evictions of the Ogieks were prompted by the need to preserve the natural ecosystem of the Mau Forest, the Court considers that this cannot, by any standard, serve as a reasonable and objective justification for the lack of recognition of the Ogieks' indigenous or tribal status and denying them the associated rights derived from such status. Moreover, the Court recalls its earlier finding that contrary to what the Respondent is asserting, the Mau Forest has been allocated to other people in a manner which cannot be considered as compatible with the preservation of the natural environment and that the Respondent itself concedes that the depletion of the natural ecosystem cannot be entirely imputed to the Ogieks. ${ }^{36}$

146. In light of the foregoing, the Court finds that the Respondent, by failing to recognise the Ogieks' status as a distinct tribe like other similar groups and thereby denying them the rights available to other tribes, violated Article 2 of the Charter.

\section{Alleged violation of Article 4 of the Charter}

\section{The Court's Assessment}

151. Article 4 of the Charter stipulates that:

"Human beings are inviolable. Every human being shall be entitled to respect for his life and the integrity of his person. No one may be arbitrarily deprived of this right"

152. The right to life is the cornerstone on which the realisation of all other rights and freedoms depends. The deprivation of someone's life amounts to eliminating the very holder of these rights and freedoms. Article 4 of the Charter strictly prohibits the arbitrary privation of life. Contrary to other human rights instruments, the Charter establishes the link between the right to life and the inviolable nature and integrity of the human being. The Court finds that this formulation reflects the indispensable correlation between these two rights.

153. The Court notes that the right to life under Article 4 of the Charter is a right to be enjoyed by an individual irrespective of the group to which he or she belongs. The Court also understands that the violation of economic, social and cultural rights (including through forced evictions) may generally engender conditions unfavourable to a decent life. ${ }^{39}$ However, the Court is of the view that the sole fact of eviction and deprivation of economic, social and cultural rights may not necessarily result in the violation of the right to life under Article 4 of the Charter.

154. The Court considers that it is necessary to make a distinction between the classical meaning of the right to life and the right to decent existence of a group. Article 4 of the Charter relates to the physical rather than the existential understanding of the right to life.

155. In the instant case, it is not in dispute between the Parties that that the Mau Forest has, for generations, been the environment in which the Ogiek population has always lived and that their livelihood depends on it. As a hunter-gatherer population, the Ogieks have established their homes, collected and produced food, medicine and ensured other means of survival in the Mau Forest. There is no doubt that their eviction has adversely affected their decent existence in the forest. According to the Applicant, some members of the Ogiek population died at different times, due to lack of basic necessities such as food, water, shelter, medicine, exposure to the elements, and diseases, subsequent to their forced evictions. The Court notes however that the Applicant has not established the causal connection between the evictions of the Ogieks by the Respondent and the deaths alleged to have occurred as a result. The Applicant has not adduced evidence to this effect.

156. In view of the above, the Court finds that there is no violation of Article 4 of the Charter. 